3. Quercitol: From a Taxonomic Marker of the Genus Quercus to a Versatile Chiral Building Block of Antidiabetic Agents / Worawalai W., Sompornpisut P., Wacharasindhu S., Phuwapraisirisan P. J Agric Food Chem. 2018. № 66 (23). P. 5741-5745.

4. Дебринюк М. Ю., Придка П. П. Дуб червоний (Quercus rubra L.) у лісових насадженнях Страдчівського НВЛК: поширення та лісівничотаксаційна характеристика. Науковий вісник НЛТУ України. 2013. Вип. 23 (17). С. 9-14.

5. Оленников Д. Н., Танхаева Л. М. Методика количественного определения группового состава углеводного комплекса растительных объектов. Химия растительного происхождения. 2006. №4. С. 29-33.

DOI https://doi.org/10.30525/978-9934-26-047-6-41

\title{
ВИЗНАЧЕННЯ ВМІСТУ ВІЛЬНИХ МОНО- ТА ДИСАХАРИДІВ У СИРОВИНІ ДІВОЧОГО ВИНОГРАДУ П'ЯТИЛИСТОЧКОВОГО
}

\author{
Коновалова О. Ю. \\ доктор фармачевтичних наук, професор, \\ завідувач кафедри фармачевтичної та біологічної хімії, фармакогнозії \\ ПВНЗ «Київський медичний університет»

\section{Ящук Б. О.} \\ асистент кафедри фармащевтичної та біологічної хімії, фармакогнозії \\ ПВНЗ «Київський медичний університет» \\ Гуртовенко I. O. \\ кандидат фармачевтичних наук, \\ старший викладач кафедри фармацевтичної та біологічної хімї, \\ фармакогнозії \\ ПВНЗ «Київський медичний університет» \\ м. Київ, Украӥна
}

Дівочий виноград п'ятилисточковий (Parthenocissus quinquefolia) північноамериканська деревоподібна листопадна ліана родини Vitaceae, по всьому світу культивується як декоративна рослина для вертикального озеленення. Представники роду Parthenocissus використовуються в народній медицині як засоби з протизапальною, загально154 
зміцнюючою, антиоксидантною, протидіабетичною дією [1, с. 70-78; 4, с. 1813-1816]. В Україні дівочий виноград п'ятилисточковий не $\epsilon$ фармакопейним видом, склад його біологічно активних речовин вивчений недостатньо, тому фітохімічні дослідження сировини Parthenocissus quinquefolia є актуальними.

Мета роботи - встановити якісний склад та кількісний вміст вільних моно- та дисахаридів у сировині дівочого винограду п'ятилисточкового. Об'єкт дослідження - листя та пагони дівочого винограду п'ятилисточкового (Parthenocissus quinquefolia), що були заготовлені у фазу масового цвітіння в липні 2020 р. у с. Лісники Києво-Святошинського району Київської області.

Дослідження проводили методом газо-рідинної хромато-масспектрометрії на системі Agilent 6890N/5973 inert (Agilent technologies, USA). Ідентифікацію проводили за часом утримання стандартів моносахаридів та 3 використанням бібліотеки мас-спектрів NIST 02, кількісний аналіз проводили шляхом додавання розчину внутрішнього стандарту в досліджувані проби [3, с. 503-510; 3, с. 633-638; 5, с. 29-33].

В результаті проведених досліджень у листі та пагонах Parthenocissus quinquefolia було ідентифіковано такі вільні моно- та дисахариди: арабіноза, фукоза, маноза, глюкоза, фруктоза, сахароза та багатоатомний спирт інозитол.

Результати кількісного визначення представлені в таблиці 1.

Таблиця 1

Кількісний вміст вільних моно- та дисахаридів у сировині Parthenocissus quinquefolia

\begin{tabular}{|c|c|}
\hline Назва сполуки & $\begin{array}{c}\text { Вміст, мг/100г } \\
\text { повітряно-сухої сировини }\end{array}$ \\
\hline Арабіноза & 12 \\
\hline Фукоза & 12 \\
\hline Маноза & 343 \\
\hline Глюкоза & 19 \\
\hline Інозитол & 175 \\
\hline Фруктоза & 70 \\
\hline Сахароза & 426 \\
\hline
\end{tabular}

Як свідчать отримані дані, за кількісним вмістом у листі та пагонах Parthenocissus quinquefolia серед ідентифікованих сполук переважають сахароза, маноза та інозитол.

Таким чином, методом газо-рідинної хроматографії-мас-спектрометрії було визначено вміст вільних моно- та дисахаридів у листі та пагонах дівочого винограду п'ятилисточкового. Встановлено, що в 
липні місяці в сировині, що досліджується, є досить високим вміст сахарози, тому в цей період iї застосування для діабетиків не $є$ доцільним.

\section{Література:}

1. Chemical characterization and antioxidant activities of polysaccharides isolated from the stems of Parthenocissus tricuspidata / Liang X., Gao Y., Fei W., Zou Y., He M. et al. Int J Biol Macromol. 2018. Nov. 119. P. 70-78.

2. Chen Y1, Xie MY, Wang YX, Nie SP, Li C. Analysis of the monosaccharide composition of purified polysaccharides in Ganoderma atrum by capillary gas chromatography. Phytochem Anal. 2009. Nov-Dec.20(6). P. 503-510.

3. Guerrant G.O., Moss C.W. Determination of monosaccharides as aldononitrile, O-methyloxime, alditol, and cyclitol acetate derivatives by gas-chromatography. Analytical Chemistry. 1984. 56. P. 633-638.

4. Phytochemical screening and antioxidant potential of Parthenocissus quinquefolia (L.) planch extracts of bark and stem / Faisal S., Perveen A., Khan Z.-U-D., Sardar A.A. Shaheen Sh., et al. Pak J Pharm Sci. 2018. 31(5). P. 1813-1816.

5. Оленников Д. Н., Танхаева Л. М. Методика количественного определения группового состава углеводного комплекса растительных объектов. Химия растительного происхождения. 2006. № 4. С. 29-33. 